\title{
Enhanced Relative Expression of Glutamate Receptor 1 Flip AMPA Receptor Subunits in Hippocampal Astrocytes of Epilepsy Patients with Ammon's Horn Sclerosis
}

\author{
Gerald Seifert, Kerstin Hüttmann, Johannes Schramm, and Christian Steinhäuser \\ Experimental Neurobiology, Department of Neurosurgery, University of Bonn, 53105 Bonn, Germany
}

\begin{abstract}
Astrocytes express ionotropic glutamate receptors (GluRs), and recent evidence suggests that these receptors contribute to direct signaling between neurons and glial cells in vivo. Here, we have used functional and molecular analyses to investigate receptor properties in astrocytes of human hippocampus resected from patients with pharmacoresistant temporal lobe epilepsy (TLE). Histopathological analysis allowed us to distinguish two forms of epilepsy: Ammon's horn sclerosis (AHS) and lesion-associated TLE. Human hippocampal astrocytes selectively expressed the AMPA subtype of ionotropic glutamate receptors. Single-cell RT-PCR found preferential expression of the subunits GluR1 and GluR2 in human astrocytes, and the expression patterns were similar in patients with AHS and lesionassociated epilepsy. The AMPA receptor-specific modulators, cyclothiazide (CTZ) and 4-[2-(phenylsulfonylamino)ethylthio]-2,6difluoro-phenoxyacetamide (PEPA), were used to investigate splice variant expression. Astrocytes of sclerotic specimens displayed a slower dissociation of CTZ from the receptor and a lower ratio of current potentiation by PEPA to potentiation by CTZ, suggesting enhanced expression of flip receptor variants in AHS versus lesion-associated epilepsy. Real-time PCR and restriction analysis substantiated this presumption by identifying elevated flip-to-flop mRNA ratios of GluR1 in single astrocytes of AHS specimens. These findings imply that in AHS, glutamate may lead to prolonged depolarization of astrocytes, thereby facilitating the generation or spread of seizure activity.
\end{abstract}

Key words: epilepsy; human; astrocyte; RT-PCR; hippocampus; patch clamp; AMPA receptor; splicing

\section{Introduction}

Glutamate is the principal excitatory neurotransmitter in the brain. Besides this physiological role, it can cause overexcitation and cell destruction in neurological disorders, e.g., epilepsy (for review, see Rogawski and Donevan, 1999). Evidence is available suggesting a role for AMPA receptors in the generation and spread of seizure activity, which in turn can cause altered receptor expression and functioning. In human epilepsy, hippocampal neurons of patients with Ammon's horn sclerosis (AHS) underwent changes in AMPA receptor subunit expression and increases in receptor density that may have enhanced excitability and seizure susceptibility (De Lanerolle et al., 1998; Eid et al., 2002). In animal models of epilepsy, seizure-induced replacement of $\mathrm{Ca}^{2+}$-impermeable by $\mathrm{Ca}^{2+}$-permeable AMPA receptors led to pyramidal cell death in the hippocampus and other brain regions (Friedman et al., 1994; Grooms et al., 2000; Sanchez et al., 2001). Moreover, hyperactivity can alter posttranscrip-

Received Aug. 22, 2003; revised Jan. 6, 2004; accepted Jan. 6, 2004.

This research was supported by Fonds der Chemischen Industrie and Deutsche Forschungsgemeinschaft (SFB TR3). We are grateful to our colleagues of the Neurosurgery and Neuropathology Departments for providing human hippocampal specimens and performing detailed histopathological evaluation. We appreciate the excellent technical assistance of I. Krahner and thank Dr. L. Daggett, who made available cDNAs of cloned human GluRs.

Correspondence should be addressed to Dr. Gerald Seifert, Experimental Neurobiology, Department of Neurosurgery, University of Bonn, Sigmund-Freud-Strasse 25, 53125 Bonn, Germany. E-mail.Gerald.Seifert@ukb.uni-bonn.de. DOI:10.1523/JNEUROSCI.3904-03.2004

Copyright $\odot 2004$ Society for Neuroscience $\quad 0270-6474 / 04 / 241996-08 \$ 15.00 / 0$ tional AMPA receptor splicing (Kamphuis et al., 1992; Pollard et al., 1993; Kamphuis et al., 1994; Rosa et al., 1999), which critically determines receptor desensitization and thereby the duration of excitation.

AMPA receptors are also expressed by glial cells (Verkhratsky and Steinhäuser, 2000), where they are able to sense glutamate released from neurons (Porter and McCarthy, 1996; Bergles et al., 2000). In astrocytes of the hippocampus, AMPA receptor activation induced a depolarization not only via the cationic receptor current but, in addition, because of block of inwardly rectifying $\mathrm{K}^{+}$channels after the $\mathrm{Na}^{+}$influx through the receptor pore (Schröder et al., 2002). Hence, in epilepsy and other pathological conditions characterized by elevated extracellular glutamate levels (Glass and Dragunow, 1995), this mechanism might enhance neuronal excitability by imposing an impaired $\mathrm{K}^{+}$buffer capacity on the astroglial network.

Advanced surgical techniques now make available for functional analyses human tissue from patients suffering from pharmacoresistent temporal lobe epilepsy (TLE). In a first attempt toward an electrophysiological characterization of astroglial AMPA receptors in human epilepsy, we compared two forms of TLE, AHS and lesion-associated epilepsy. In this study, human astrocytes were found to express functional AMPA receptors with an intermediate $\mathrm{Ca}^{2+}$ permeability, and preliminary data indicated alterations in flip/flop splicing in AHS (Seifert et al., 2002). Here we set out to investigate the supposed alterations in more 


\section{A AHS, lane 6}
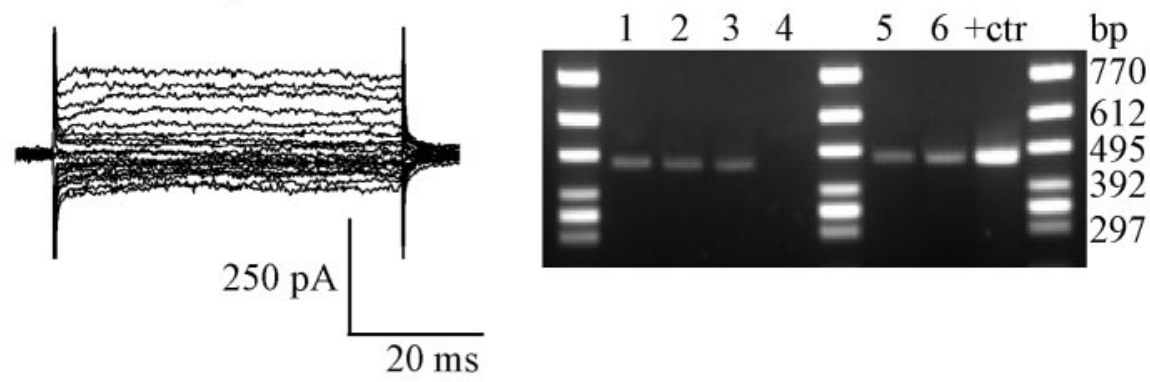

B
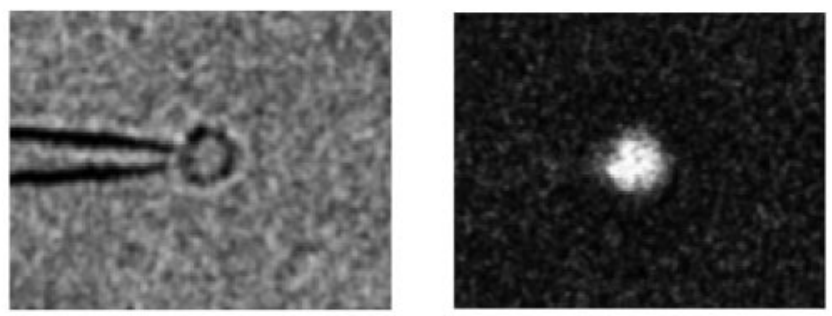

Figure 1. Identification of isolated astrocytes after electrophysiological characterization. A, Current pattern of an astrocyte freshly isolated from the CA1 stratum radiatum of an AHS specimen (top, left). Whole-cell currents were evoked by depolarizing the membrane between -130 and $+20 \mathrm{mV}$ ( $50 \mathrm{msec}, 10 \mathrm{mV}$ increments; holding potential $-70 \mathrm{mV}$ ). The right panel depicts amplified S100 $\beta$ CDNAs of individual cells (lines 1-6), including the one displayed in the left panel (lane 6), and of total RNA from human hippocampus that was used to test for the specificity of the method (lane $+\mathrm{ctr}$ ). The length of the PCR product was $470 \mathrm{bp}$; one cell was $S 100 \beta$ negative (lane 4). B, Alternatively, a cell on top of the recording pipette was immunolabeled for $S 100 \beta$ to confirm its astroglial origin (bottom).

detail, by combining functional analysis with semiquantitative transcript analysis (1) to discover the subunit(s) that make up the human receptors and (2) to identify those subunits that potentially underwent changes in the splice status.

\section{Materials and Methods}

Patient evaluation. Patients suffering from pharmacoresistant TLE were evaluated by extensive invasive and noninvasive methods to identify the epileptic focus (Engel, 1993; Hufnagel et al., 1997; Kral et al., 2002). In all cases, removal of the hippocampus was clinically indicated to achieve seizure control. Informed consent was obtained from all patients for further electrophysiological evaluation, and all procedures were approved by the Ethics Committee of the University Medical Center of Bonn and conform to the standards set by the Declaration of Helsinki (1989). On the basis of preclinical and histopathological evaluation, patients suffered from AHS or lesion-associated epilepsy. AHS was diagnosed in 29 patients, exhibiting reactive astrogliosis and pronounced neuronal loss in the CA1 region. Another 25 epilepsy patients possessed lesions in the temporal lobe not involving the hippocampus, with no or only minor morphological changes in the hippocampus. In these cases, subsequent analysis revealed extrahippocampal low-grade glioma $(n=$ $7)$, hamartoma $(n=2)$, pseudocystic defects, cavernoma $(n=3)$, posttraumatic focal lesions after craniocerebral injury $(n=2)$, failure of differentiation or migration, cortical dysplasia $(n=5)$, and epilepsy without significant morphological and pathological changes in the hippocampus formation $(n=5)$.

Tissue preparation and cell isolation. Immediately after resection, the tissue was placed in ice-cold saline and cut into 3-4 mm transverse segments, and $150-\mu \mathrm{m}$-thick slices were prepared for in situ recording (Hinterkeuser et al., 2000). Cells were acutely isolated as described (Seifert et al., 2002). Briefly, 300- $\mu \mathrm{m}$-thick slices were prepared with a vibratome and stored in a $\mathrm{Ca}^{2+}$-free solution composed of (in mM): 150 $\mathrm{NaCl}, 5 \mathrm{KCl}, 2 \mathrm{MgSO}_{4}, 1$ sodium pyruvate, 10 glucose, 10 HEPES, $\mathrm{pH} 7.4$, gassed with oxygen at $6^{\circ} \mathrm{C}$. After $30-60 \mathrm{~min}$ the slices were incubated in papain $(24 \mathrm{U} / \mathrm{ml}$, supplemented with $0.24 \mathrm{mg} / \mathrm{ml}$ cysteine)-containing solution for $45 \mathrm{~min}$. After thorough wash, the slices were stored in $\mathrm{Ca}^{2+}$.
$10 \mu \mathrm{m}$

free saline at $6^{\circ} \mathrm{C}$. The stratum radiatum of the CA1 subregion was carefully dissected, the tissue was transferred to a bath chamber, and the cells were dispersed by gentle manipulation with tungsten needles under microscopic control (Axiovert 135, Zeiss, Jena, Germany).

Electrophysiological recording. Membrane currents were obtained with the patch-clamp technique in the whole-cell mode. Current signals were amplified (EPC-7, HEKA Elektronik, Lambrecht, Germany), filtered at $3 \mathrm{kHz}$, sampled at $10 \mathrm{kHz}$, and monitored with TIDA software (HEKA). The external solutions could be rapidly exchanged by means of a pneumatically controlled application system (Seifert and Steinhäuser, 1995). Electrophysiological measurements were performed at room temperature $\left(22^{\circ} \mathrm{C}\right)$. The standard bath solution contained (in mM): $150 \mathrm{NaCl}, 5 \mathrm{KCl}, 2 \mathrm{MgSO}_{4}, 2$ $\mathrm{CaCl}_{2}, 10$ glucose, 10 HEPES, pH 7.4. The pipette solution contained (in $\mathrm{mM}$ ): $130 \mathrm{KCl}, 2$ $\mathrm{MgCl}_{2}, 0.5 \mathrm{CaCl}_{2}, 5$ BAPTA, $3 \mathrm{Na}_{2}$-ATP, 10 HEPES, pH 7.25. Membrane capacitance $\left(C_{\mathrm{M}}\right)$ and series resistance $\left(R_{\mathrm{S}}\right)$ were determined from the current transients evoked by a $10 \mathrm{mV}$ test pulse depolarizing the cells from -70 to $-60 \mathrm{mV}$ (sampling rate $30 \mathrm{kHz}$; filter $10 \mathrm{kHz}$ ). $C_{\mathrm{M}}$ and $R_{\mathrm{S}}$ compensation $(40-50 \%)$ were used to improve voltage-clamp control. For current-voltage analysis of glial AMPA receptors in situ, $\mathrm{Na}^{+}$and $\mathrm{K}^{+}$channels and neuronal transmitter release were blocked adding $\mathrm{BaCl}_{2}$ (10 mM), 4-aminopyridine (5 mM), tetrodotoxin (TTX; $1 \mu \mathrm{M}$ ), and $\mathrm{CdCl}_{2}(30 \mu \mathrm{M})$ to the bath solution. $\mathrm{NaCl}$ concentration was reduced to $135 \mathrm{~mm}$ to ensure a constant osmolarity. Patch pipettes were pulled from borosilicate capillaries (Hilgenberg, Malsfeld, Germany; resistance $4 \mathrm{M} \Omega$ ). TTX was purchased from Alomone Labs (Jerusalem, Israel), GYKI53655 was purchased from Tocris (Bristol, UK), and all the other salts and reagents were obtained from Sigma (Taufkirchen, Germany). 4-[2-(Phenylsulfonylamino)ethylthio]-2,6difluoro-phenoxyacetamide (PEPA) was a kind gift from Dr. M. Sekiguchi (Department of Degenerative Neurological Diseases, National Institute of Neuroscience, Tokyo, Japan). PEPA and cyclothiazide (CTZ) were dissolved in dimethyl sulfoxide (DMSO) at $100 \mathrm{~mm}$ before dilution (final DMSO concentrations were 0.05 and $0.1 \%$, respectively).

Identification of human astrocytes. Human hippocampal astrocytes were identified according to their morphological, immunocytochemical, and electrophysiological criteria as described (Hinterkeuser et al., 2000). We focused on cells with complex current patterns, whereas cells with predominating time- and voltage-independent currents were not considered. Glial cells did not show spontaneous activity either in situ or after their acute isolation, and positive current injections never produced action potentials. Single-cell RT-PCR subsequent to functional analysis detected $S 100 \beta$ transcripts in these cells in situ (Hinterkeuser et al., 2000) or after their acute isolation (five of six cells) (Fig. 1A), thus identifying them as astrocytes. Moreover, after electrophysiological characterization, isolated cells on top of the patch pipette were immunolabeled with anti-S100 $\beta$ antibody (Seifert et al., 1997b). The cell was fixed in $4 \%$ paraformaldehyde (10 $\mathrm{min}$ ) and permeabilized with Triton X-100 (1\%; $10 \mathrm{~min})$. After incubation in $10 \%$ swine serum in PBS (15 min), the primary antibody (rabbit anti-S100 $\beta$; Swant Swiss Antibodies, Bellinzona, Switzerland; 1:2000 in 10\% swine serum) was applied for $2 \mathrm{hr}$. The cell was perfused with $10 \%$ swine serum $(15 \mathrm{~min})$ and exposed to Cy3-conjugated goat anti-rabbit immunoglobulins (Dianova, Hamburg, Germany; 1:100 in 10\% swine serum; $30 \mathrm{~min}$ ). Subsequently, the cell was inspected in an Axiovert 135 fluorescence microscope (Zeiss). For the control of nonspecific labeling, the primary antibody was omitted or non-immune serum was used; no immunoreactivity was observed under 
either condition. Seven of eight freshly suspended cells tested after their functional analysis proved to be $S 100 \beta$ positive (Fig. $1 B$ ).

Single-cell RT-PCR. Cell harvesting and RT followed a strategy described previously (Seifert et al., 2003). RT was performed in a final volume of $\sim 10 \mu \mathrm{l}$, adding buffer RT (Qiagen, Hilden, Germany), deoxyribonucleotide triphosphates (dNTPs; final concentration $4 \times 250 \mu \mathrm{M}$; Applied Biosystems, Weiterstadt, Germany), random hexanucleotide primer (50 $\mu \mathrm{M}$; Roche, Mannheim, Germany), $20 \mathrm{U}$ RNasin (Promega, Madison, WI), and $0.5 \mu \mathrm{l}$ Sensiscript reverse transcriptase (Qiagen). Single-strand cDNA synthesis was performed at $37^{\circ} \mathrm{C}$ for $1 \mathrm{hr}$. A nested PCR was performed, using the product obtained after the first round ( 3 $\mu \mathrm{l})$ as a template for the second round. Reaction conditions and purification of PCR products followed the protocol described by Seifert et al. (2003).

The primer pair used for the first PCR round amplified all AMPA receptor subunits, human glutamate receptor 1 (hGluR1)-hGluR4. The sense primer was $5^{\prime}$-TGTGCATTGTYTTTGCCTACATTGG, having one mismatch with hGluR3 and hGluR4, respectively. The antisense primer was 5'-CTCAGRGCRCTBGTCTTKTCCTT, having one mismatch with hGluR2 and hGluR4, respectively. The positions (position 1 is the first base of the initiation codon) of sense primers were 1622 on hGluR1 (GenBank accession number M64752), 1643 (hGluR2, L20814), 1670 (hGluR3, U10301), and 1646 (hGluR4, U16129). The respective positions of the antisense primers were 2383, 2404, 2437, and 2407 on hGluR1-4, respectively. The nested sense primers were $5^{\prime}$-GGACGGGACCAGACAACCAG for hGluR1 (position 1717), 5'-TGAAGATGGAAGAGAAACACAAAG for hGluR2 (position 1731), 5'-ACCCAC AAAGTCCTCCTG for hGluR3 (position 1775), and 5'-GAAGGACCCAGCGACCAGCC for hGluR4 (position 1747). The nested antisense primer was common for all subunits and had the composition 5'-TCGTACCACCATTTGTTTTTCA, having one mismatch with hGluR1 (positions 2327, 2348,2381 , and 2351 for hGluR1-4, respectively). The annealing temperatures were $51^{\circ} \mathrm{C}$ for hGluR1, hGluR2, and hGluR4 and $54^{\circ} \mathrm{C}$ for hGluR3. Products were identified by agarose gel electrophoresis (1.5\%; stained with ethidium bromide) using a molecular weight marker ( $\Phi$ X174 HincII digest; Eurogentec, Seraing, Belgium). The expected amplified fragment lengths were 632, 639, 630, and $626 \mathrm{bp}$ for hGluR1-4. Detection of S100 $\beta$ mRNA followed the protocol described by Hinterkeuser et al. (2000).

Restriction analysis. For restriction analysis, the second PCR round was again performed, with a reduced cycle number ( 25 cycles). The product was purified and dissolved in $25 \mu \mathrm{l}$ water. The splicing status of the hGluR cDNAs was identified with the splice variant-specific restriction endonucleases AluI (cut hGluR1 flip, yielding a 609 bp and a $23 \mathrm{bp}$ fragment), HpaI (hGluR2 flop, 571 and 68 bp), HpaI (hGluR3 flop, 562 and $68 \mathrm{bp}$ ), and BsaHI (hGluR4 flip, 590 and $36 \mathrm{bp}$ ), all purchased from New England Biolabs (Frankfurt, Germany). Seven microliters of the respective purified PCR product were incubated in $10 \mathrm{U}$ of restriction enzyme (total volume $15 \mu \mathrm{l} ; 6 \mathrm{hr}, 37^{\circ} \mathrm{C}$ ). The cDNA fragments were separated with electrophoresis and agarose, allowing resolution of $10 \mathrm{bp}$ differences (2\% Separide gel matrix, 50 bp length marker; Invitrogen, Karlsruhe, Germany). The gels were stained with ethidium bromide and evaluated with a digital imaging system (AlphaImager, San Leandro, CA). Exposure times were adapted to the respective staining intensities, and optical densities of the fragments were calculated after background correction. The fractions of flip versus flop (flip/flop ratios) were obtained for each restriction enzyme by comparing the optical densities of corresponding digested and undigested bands (normalized to 100\%). To enhance reliability, the second PCR and restriction analysis were always performed twice.

For a positive control, total RNA was prepared from human hippocampal specimens using Trizol (Invitrogen). Then a two-round RTPCR was performed with $2 \mathrm{ng}$ of total RNA and primers as described above. Subsequent gel analysis did not detect unspecific products. PCR products obtained from human total RNA and from cloned hGluRs were digested with the restriction enzymes above, yielding fragments of the expected lengths. In the case of cloned hGluRs, digestion was complete. Omission of reverse transcriptase or aspiration of bath solution served as negative controls.

Determination of flip/flop ratios with real-time PCR. An ABI PRISM
Table 1. Primers and TaqMan probes used for real-time PCR

\begin{tabular}{|c|c|c|c|}
\hline $\begin{array}{l}\text { Primers and } \\
\text { probes }\end{array}$ & Nucleotide sequences & Position & Product lengths \\
\hline hGluR flip se & 5'-TCAGTGAGSMAGGCGTCTTAGA & $\begin{array}{l}2300,2321 \\
2354,2324\end{array}$ & \\
\hline hGluR flip as & 5'-GTCTTGTCCTTACTTCCRGAGTC & $\begin{array}{l}2371,2392, \\
2425,2395\end{array}$ & \\
\hline hGluR flip probe se & $\begin{array}{l}\text { FAM-5'-AAGCTGAAAARCAAATGGTGG- } \\
\text { TACGATAAAGG-TAMRA }\end{array}$ & $\begin{array}{l}2323,2344 \\
2377,2347\end{array}$ & $94 \mathrm{bp}$ \\
\hline hGluR flop se & 5'-TTAACCTSGCAGTATTAAAACTGA & $\begin{array}{l}2279,2300 \\
2333,2303\end{array}$ & \\
\hline hGluR flop as & $5^{\prime}$-TGGARTCACCTCCCCCGCTG & $\begin{array}{l}2364,2375 \\
2418,2388\end{array}$ & \\
\hline $\begin{array}{l}\text { hGluR flop probe } \\
\text { se }\end{array}$ & $\begin{array}{l}\text { FAM-5'-TGGACAAATTGAAAAACAAATG- } \\
\text { GTGGTACGA-TAMRA }\end{array}$ & $\begin{array}{l}2318,2339 \\
2372,2342\end{array}$ & $105 b p$ \\
\hline
\end{tabular}

Position 1 is the first nucleotide of the initiation codon. " $\mathrm{e}$ " and "as" mark sense and antisense primers and probes. The TaqMan probes were labeled at $5^{\prime}$ with 6-carboxyfluorescein (FAM) and at $3^{\prime}$ with 6-carboxytetramethylrhodamine (TAMRA). All primers and probes were located on conserved nucleotides for each respective splice form. The antisense hGluR flip primer has one mismatch with hGluR2 and 4. The sense hGluR flop primer has one mismatch with hGluR2 and 4 and two with hGluR1.

7700 Sequence Detection System (PE Applied Biosystems, Foster City, CA) was used for cDNA quantification. This system permits a quantitative detection of PCR product accumulation during each cycle by using the fluorogenic 5' -nuclease assay (Holland et al., 1991). hGluR flip and flop transcripts were investigated with the TaqMan PCR Core Reagent Kit (PE Applied Biosystems); primer sequences and TaqMan probes are given in Table 1 and were purchased from Eurogentec. The reaction volume was $12.5 \mu \mathrm{l}$. The cDNA of the first single-cell PCR round was used as a template for the following reactions (aliquots of $0.5 \mu \mathrm{l}$ ). In each PCR run, hGluR flip and flop of single cells were recorded in parallel with mixtures of cloned hGluR flip/flop cDNAs for calibration (96-well plates). The optimized reaction mixture contained TaqMan buffer, $3 \times$ $200 \mu \mathrm{M}$ dNTPs (dATP, dCTP, dGTP), $400 \mu \mathrm{M}$ dUTP, $2.5 \mathrm{~mm} \mathrm{MgCl}_{2}, 0.3$ U AmpliTaq Gold TaqDNA polymerase, $0.125 \mathrm{U}$ uracil- $N$-glycosylase (UNG), $100 \mathrm{~nm}$ fluorogenic TaqMan probe, and $300 \mathrm{~nm}$ of each PCR primer. The hGluR splice form-specific oligonucleotides that were used are depicted in Table 1 . After incubation $\left(50^{\circ} \mathrm{C}, 2 \mathrm{~min}\right), \mathrm{UNG}$ was denaturated at $95^{\circ} \mathrm{C}(10 \mathrm{~min})$, followed by 60 PCR cycles (denaturation at $95^{\circ} \mathrm{C}, 15 \mathrm{sec}$; primer annealing and extension at $59^{\circ} \mathrm{C}, 60 \mathrm{sec}$ ). The fluorescence intensity was read out during each annealing-extension step of the respective PCR cycle. Fluorescence emission at dye-specific wavelengths was monitored consecutively during each PCR cycle. After normalization of emission intensity to an internal reference, $\Delta R_{\mathrm{n}}$, the threshold cycle $\left(C_{\mathrm{T}}\right)$ was determined in the exponential phase of the PCR.

Specificity and efficiency of the reaction conditions were optimized using cloned human AMPA receptor cDNA. The primers and TaqMan probes were designed for amplification of the respective splice variant, either flip or flop, and no PCR products were amplified when the cloned human GluR cDNA of the opposite splice form was used as PCR target (data not shown). The PCR conditions were optimized to amplify both splice forms of GluR1-4 with similar efficiency, using serial dilutions of GluR cDNA (from $4 \times 10^{-17}$ to $3.125 \times 10^{-19} \mathrm{~mol}$ ). Figure $2 \mathrm{~A}$ illustrates that increasing amounts of the respective cloned human cDNA resulted in a continuous decrease of the $C_{\mathrm{T}}$ values. The resulting logarithmic functions for GluR1 flip and flop displayed the same slope, indicating similar amplification efficiency (Medhurst et al., 2000). Next, defined flip/flop ratios were used (total cDNA concentration was kept constant at $2 \times 10^{-17} \mathrm{~mol}$ ), and the flip and flop primers and probes were tested to obtain the respective $C_{\mathrm{T}}$ values. The differences in $C_{\mathrm{T}}$ values between flip and flop PCR runs $\left(\Delta C_{\mathrm{T}}\right)$ were plotted against the flip/flop ratio of the target cDNA, yielding calibration curves for an estimation of this ratio in cDNA obtained from epilepsy patients (Fig. $2 B$ ).

Data analysis. Receptor desensitization was fitted by a single or double exponential according to the equation $I(t)=I_{\mathrm{ss}}+A \exp \left(-t / \tau_{1}\right)+B \exp$ $\left(-t / \tau_{2}\right)$, where $I_{\mathrm{ss}}$ is the steady-state current at $t=\infty, A$ and $B$ are amplitude factors, and $\tau_{1}$ and $\tau_{2}$ are the corresponding time constants. The degree of receptor desensitization was defined by desensitization $=$ 

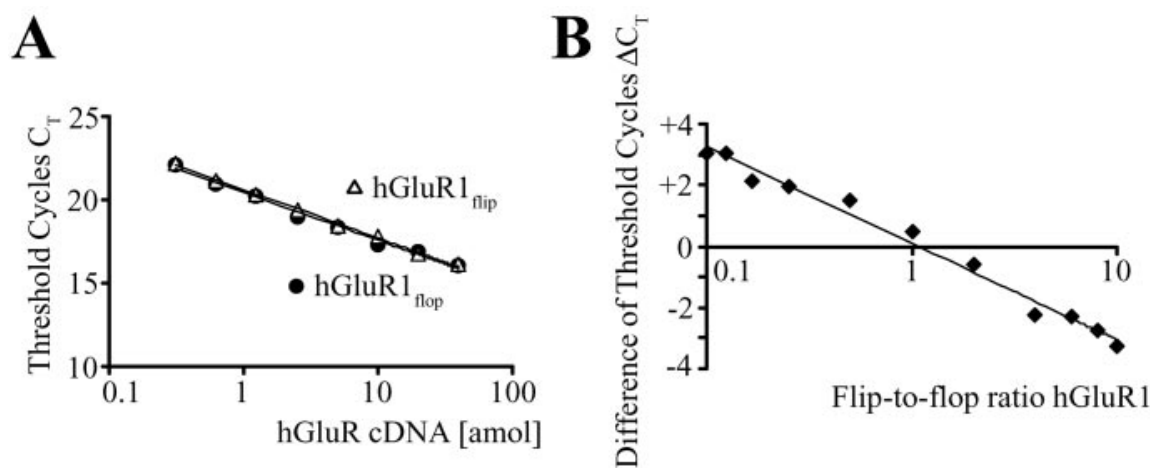

Figure 2. Calibration of real-time $P C R$ approach by cloned human GluR flip and flop cDNAs. $A$, Calibration of real-time $P C R$ approach was demonstrated for GluR1 flip and flop cDNAs considered as an example. Threshold cycles were determined at various dilutions, and the almost identical slopes of the curves indicated the same amplification efficiency for both splice variants. $B$, Standard $\Delta C_{\mathrm{T}}$ curves were obtained for defined GluR1 flip/flop ratios at constant CDNA concentration of $2 \times 10^{-17} \mathrm{~mol} . \Delta C_{\mathrm{T}}$ was determined by subtracting $C_{\mathrm{T}, \text { GluRflop }}$ from $C_{\mathrm{T}, \text { GluRflip }}$ at corresponding flip/flop ratios.

$\left.\left.100 \%\left[I_{\text {peak }}-I_{\text {ss }}\right) / I_{\text {peak }}\right)\right]$, where $I_{\text {peak }}$ is the maximal receptor current and $I_{\text {ss }}$ is the steady-state current in the presence of the agonist, which was determined $300 \mathrm{msec}$ after the onset of the response. Data are given as mean \pm SD. Significance differences were evaluated according to the Student's $t$ test. The level of significance was set at $p \leq 0.05$.

\section{Results}

Astrocytes from epilepsy patients express glutamate receptors of the AMPA subtype

Application of the AMPA-kainate receptor agonist, kainate, evoked receptor responses in hippocampal astrocytes from surgical specimens in situ, with the current density in cells from AHS and lesion cases being the same (Seifert et al., 2002). I- $V$ relationships of kainate-induced currents were obtained by repetitively stepping the membrane potential between -160 and $+100 \mathrm{mV}$ and subtracting control currents before drug application from those recorded in the presence of the agonist (Fig. 3A, bottom panel). In agreement with the latter study using acutely isolated cells, the specific AMPA-receptor modulator, CTZ (100 $\mu \mathrm{M}, 30$ sec), led to a significant increase of the kainate responses in situ, both in AHS and in lesion cases ( $n=10$; six patients) (Fig. $3 A$, right panel). The kainate $I-V$ relations were linear, and currents reversed close to $0 \mathrm{mV}$ (Fig. $3 A$, bottom panel). In another set of experiments, after taking kainate $(0.5 \mathrm{mM})$ control responses, the slices were exposed to the specific AMPA receptor antagonist GYKI53655 $(100 \mu \mathrm{M})$, and then kainate was co-applied with GYKI53655. In both forms of epilepsy, the antagonist completely blocked the responses in a voltage-independent manner $(n=7$; five patients) (Fig. 3B, top panel). These data proved the presence of a selective expression of AMPA receptors in the human astrocytes, whereas functional kainate receptors were absent. Similar to astrocytes in rodent hippocampus (Jabs et al., 1994; Schröder et al., 2002), kainate not only activated a receptor conductance but simultaneously blocked outward and inward rectifying $\mathrm{K}^{+}$ currents ( $n=12$, six patients; data not shown).

\section{Analysis of glial AMPA receptor desensitization}

Fast application of glutamate to acutely isolated astrocytes induced rapidly desensitizing inward currents, with the amplitudes being the same in AHS (maximal amplitude, $I_{\max }=388 \pm 174$ $\mathrm{pA}$; current density, $164 \pm 100 \mathrm{pA} / \mathrm{pF} ; \mathrm{V}=-70 \mathrm{mV} ; n=29 ; 16$ patients) and lesion cases $\left(I_{\max }=500 \pm 404 \mathrm{pA}\right.$; current density, $142 \pm 121 \mathrm{pA} / \mathrm{pF} ; n=31 ; 18$ patients). The glutamate-induced currents almost completely desensitized (AHS: by $97.9 \pm 1.3 \%$; $n=29$; lesion: $97.5 \pm 2.7 \% ; n=31$ ) (Fig. 4 A). Current decay could be well fitted by a single exponential, revealing significantly faster desensitization kinetics for cells of the lesion group $(\tau=6.2 \pm 0.9 \mathrm{msec} ; n=31)$ as compared with AHS astrocytes (7.6 \pm 1.4 msec; $n=29$ ) (Fig. 4A). Currents were completely and reversibly blocked by GYKI53655 $(50 \mu \mathrm{M})(n=5$; data not shown).

To further investigate this issue, we compared the sensitivity of the receptors to CTZ and PEPA, two specific AMPA receptor modulators blocking receptor desensitization in a splice form-specific manner (Partin et al., 1994; Sekiguchi et al., 1997). After a control application of glutamate $(1 \mathrm{~mm}, \mathrm{~V}=-70 \mathrm{mV})$, individual cells were exposed to PEPA $(50 \mu \mathrm{M})$ and CTZ $(100 \mu \mathrm{M})(30 \mathrm{sec}$ each), respectively, and then glutamate was again applied rapidly (Fig. $4 B, C$ ). Regardless of the form of epilepsy, CTZ led to a significant (three- to fourfold) increase of the responses, within 2 sec after onset: the amplified current declined by $16 \pm 8 \%(n=9$; five patients) in lesion cases but remained almost stationary in AHS (reduction by $6 \pm 4 \% ; n=7$; four patients). PEPA had a stronger effect on the steady-state currents of astrocytes from lesion patients $(n=9)$ compared with AHS $(n=7)$. The ratio of the potentiation by PEPA to the potentiation by CTZ (P/C ratio) (Sekiguchi et al., 1998) in the same cell was obtained by dividing the respective current amplitudes $2 \mathrm{sec}$ after onset of the responses. The $\mathrm{P} / \mathrm{C}$ ratio was significantly larger in cells from lesion-associated specimens $(0.36 \pm 0.18 ; n=6$; four patients) compared with AHS $(0.13 \pm 0.07 ; n=5$; four patients). These findings further corroborated the idea that flip receptor versions are more abundant in AHS.

\section{Identification of AMPA receptor subunits and splice variant expression in human astrocytes}

After recording in situ or from isolated cells, the cytoplasm of the respective astrocyte was harvested for transcript analysis. Two round single-cell RT-PCRs revealed a relative frequency of 59, 97, 41 , and $72 \%$ for the astroglial GluR1-4 subunits, respectively (Fig. 5A). The GluR2 subunit, controlling the $\mathrm{Ca}^{2+}$ permeability of AMPA receptors, was found in almost all cells ( 28 of 29 cells), and 20 cells (69\%) coexpressed GluR2 together with GluR4. In individual cells, the subunit combination GluR1, -2 , and -4 was most abundant (Fig. 5B). This expression pattern did not differ between astrocytes from AHS ( $n=16 ; 13$ patients) or lesion cases ( $n=13 ; 10$ patients) (Fig. $5 C$ ).

To investigate the flip/flop status of the respective subunit and identify the subunit(s) that potentially underwent changes in alternative splicing, the second PCR was repeated with a reduced number of cycles, and the PCR products were subjected to restriction analysis. Overall, the GluR subunits were preferentially expressed in the flip form, which agreed with the robust current potentiation by CTZ. Strikingly, astrocytes from AHS patients expressed a significantly enhanced level of GluR1 flip compared with lesion cases, whereas flip/flop splicing of GluR2-4 did not differ in the two forms of epilepsy (Table 2, Fig. 5D). 

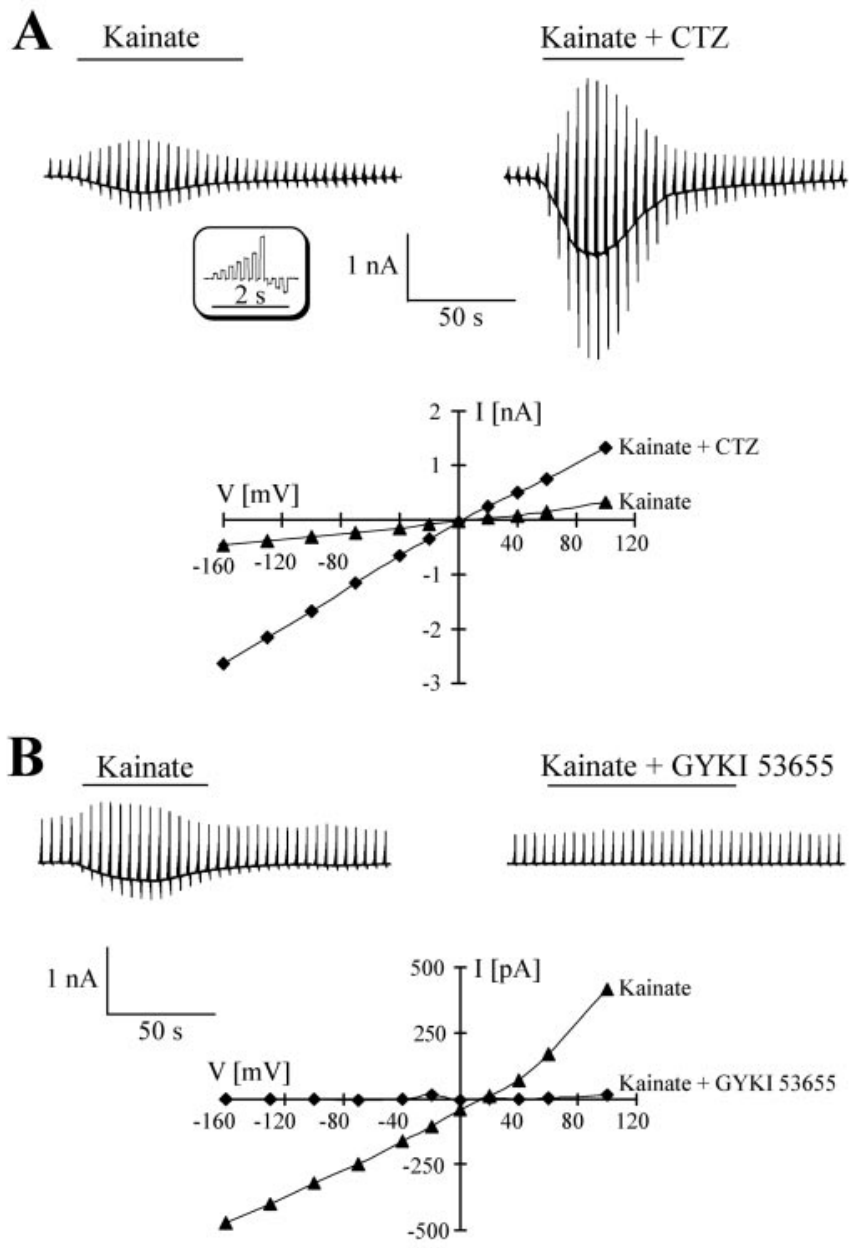

Figure 3. Identification of glutamate receptors expressed by human astrocytes in situ. $A$, An astrocyte in a hippocampal specimen from an AHS patients was clamped repetitively between -160 and $+100 \mathrm{mV}$ ( $100 \mathrm{msec}$; holding potential of $-70 \mathrm{mV}$; see inset). Bath application of $500 \mu \mathrm{m}$ kainate evoked current responses ( $-242 \mathrm{pA}$ at $-70 \mathrm{mV}$; top left). After wash, the same cell was incubated with $100 \mu \mathrm{M}$ CTZ (30 sec), and then kainate was applied again with CTZ, yielding a fivefold increase of the responses (to $-1153 \mathrm{pA}$ at $-70 \mathrm{mV}$; top right). The $\mathrm{I}-\mathrm{V}$ curves of the responses (bottom) were constructed by subtracting current amplitudes at corresponding membrane potentials before and during kainate application. Currents reversed at +4 $\mathrm{mV} . \quad B$, In another cell (AHS), using the above stimulation protocol, kainate (500 $\mu \mathrm{m})$-induced currents ( $-273 \mathrm{pA}$ at $-70 \mathrm{mV}$; top left) were completely blocked when the tissue was perfused with GYKI53655 (100 $\mu \mathrm{m} ; 30 \mathrm{sec}$ ), and then kainate was c0-applied again with GYKI (top right). $I-V$ curves (bottom) were constructed as described above.

\section{Quantification of flip/flop splice variant ratios using real-time PCR}

Single-cell real-time PCR was performed to get a quantitative measure of the differences in astroglial receptor splicing in AHS versus lesion-associated epilepsy. The optimized PCR protocol (see Materials and Methods) was applied to cDNA obtained from individual, functionally characterized hippocampal astrocytes. The consecutive increase of fluorescence intensity normalized to a passive fluorescent reference, $\Delta R_{\mathrm{n}}$, was plotted against PCR cycle number. Figure 6 depicts the amplification curves of GluR flip and flop variants of cDNA obtained from two astrocytes, one from a lesion case and one from an AHS patient. The detection threshold was set at $\Delta R_{\mathrm{n}}=0.17$ (indicated by the dashed line). Although the $C_{\mathrm{T}}$ values for $\mathrm{GluR}_{\text {flip }}$ were almost the same in the two cells, the initial cDNA level encoding $\mathrm{GluR}_{\text {flop }}$ was lower in AHS, because a higher $C_{\mathrm{T}}$ number was necessary to reach the threshold (Fig. 6). Comparison of the difference $\Delta C_{\mathrm{T}}=C_{\mathrm{T}, \text { GluRflip }}$
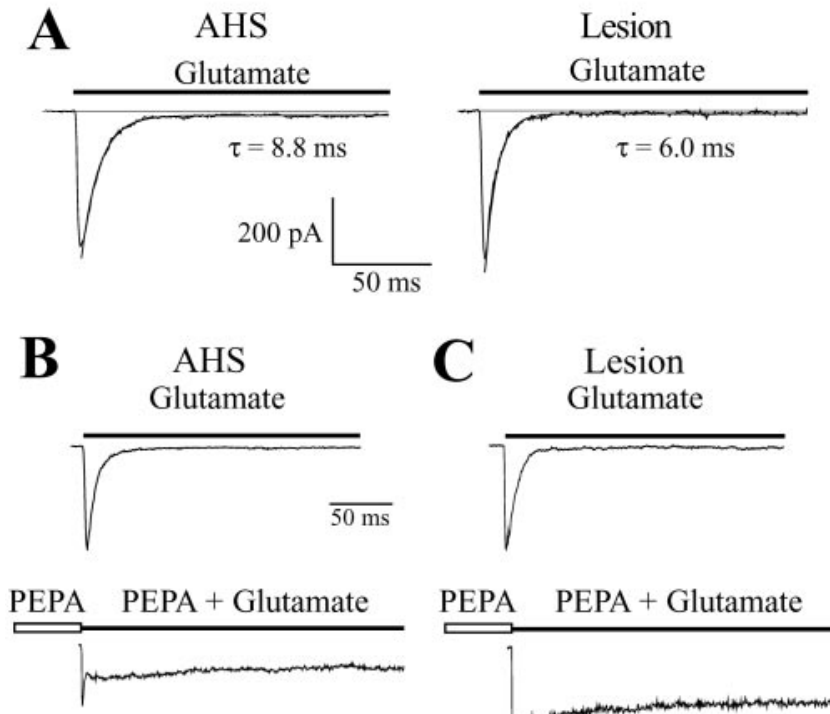

C Lesion

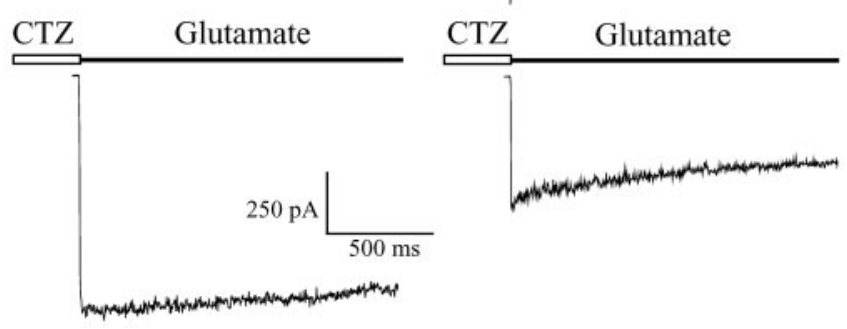

Figure 4. Desensitization properties and case-dependent modulation by CTZ and PEPA of glutamate-evoked currents in acutely isolated human astrocytes. $A$, Fast application of glutamate $(1 \mathrm{~mm})$ elicited inward currents in astrocytes from AHS and lesion specimens. The glutamate responses desensitized rapidly and almost completely, with a monoexponential current decay. Time constants of current desensitization were as indicated. $B, C$, After glutamate $(1 \mathrm{~mm})$ application, the cells were exposed to PEPA ( $50 \mu \mathrm{m} ; 30 \mathrm{sec})$, and then glutamate and PEPA were co-applied again. After washout, the same cell was incubated in (TZ (100 $\mu \mathrm{m} ; 30 \mathrm{sec})$, and then glutamate was applied. CTZ had a larger effect on the astrocyte from an AHS specimen ( $B)$, whereas PEPA preferentially enhanced the steady-state response of the lesion cell ( $C$. Holding potential was $-70 \mathrm{mV}$.

- $C_{\mathrm{T}, \mathrm{GluRflop}}$ revealed a significant difference for cells from AHS $\left(\Delta C_{\mathrm{T}}=-3.3 \pm 2.2 ; n=11 ; 11\right.$ patients $)$ versus lesion patients $\left(\Delta C_{\mathrm{T}}=-0.1 \pm 2.6 ; n=6\right.$; four patients). The calibration of $\Delta C_{\mathrm{T}}$ values as a function of the flip/flop ratio using cloned human GluR cDNA (Fig. $2 B$ ) gives an estimation of flip/flop splicing in individual cells. Comparing the above mean $\Delta C_{\mathrm{T}}$ values with the calibration curve corroborated a high expression of flip variants in AHS $(\sim 80 \%)$ and a more balanced flip/flop ratio in astrocytes from lesion-associated epilepsy ( $53 \%$ flip).

\section{Discussion}

Astrocytes are endowed with ionotropic glutamate receptors, and accumulating evidence suggests that dysfunction of the receptors is involved in brain damage and disease (Seifert and Steinhäuser, 2001). The functional properties of transmitter receptors, including glutamate receptors, in human astrocytes are essentially unknown. A first study recently reported that astrocytes in the hippocampus of patients suffering from pharmacoresistant TLE express AMPA receptors with an intermediate $\mathrm{Ca}^{2+}$ permeability, and suggested differences in flip/flop splicing of the receptors in patients with different forms of TLE (Seifert et al., 2002). Here we set out to investigate this issue in more detail, by combining patch clamp with transcript analyses in the same individual cell to 
A

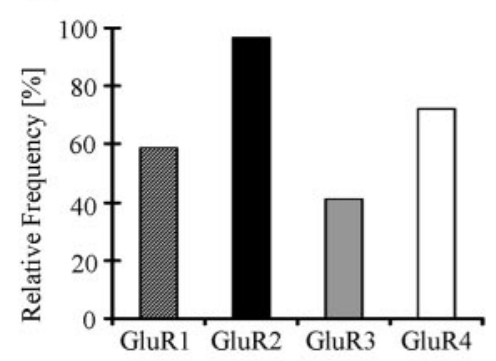

C
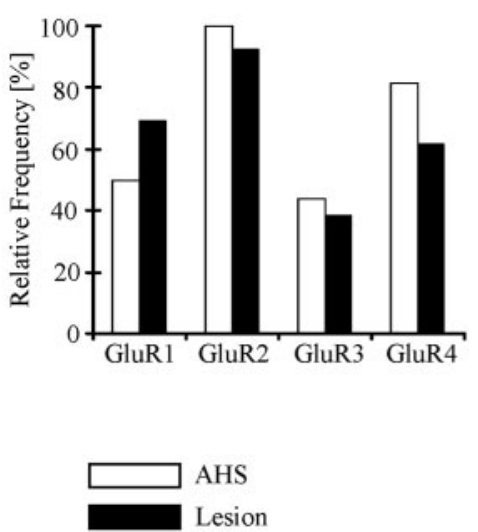

B

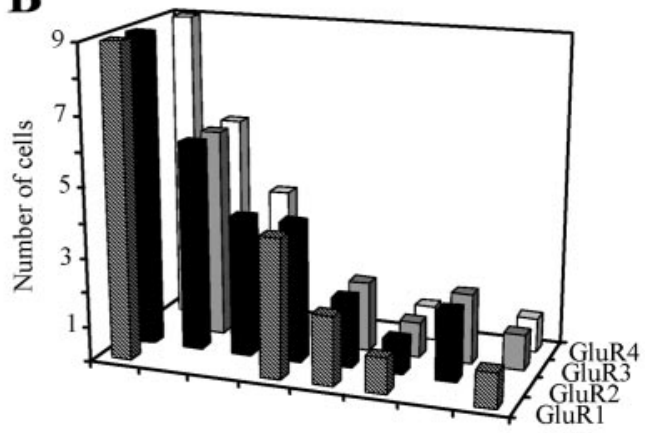

D

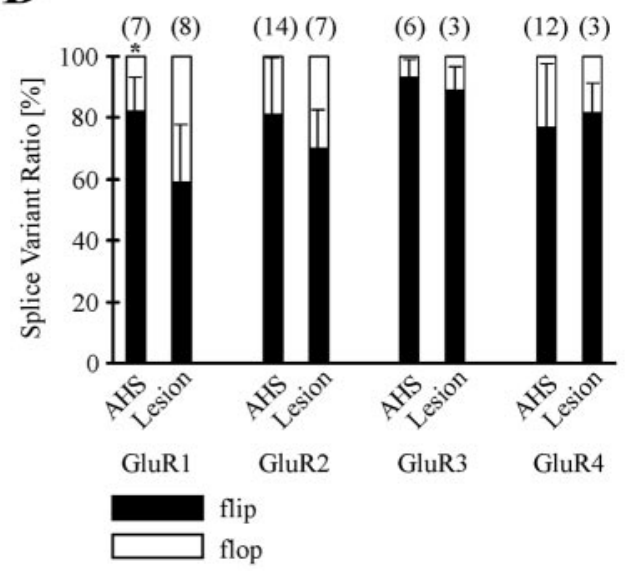

Figure 5. AMPA receptor subunit expression and splicing by human astrocytes. A, After electrophysiological characterization, the cytoplasm of the respective cell was harvested and analyzed with single-cell RT-PCR. The histogram shows the relative frequency of GluR subunit expression in human astrocytes $(n=29)$. $B$ depicts the subunit combinations expressed by individual cells. Coexpression of GluR1, GluR2, and GluR4 was found most frequently. C, Cells from AHS ( $n=16$; open bars) and lesion specimens ( $n=13$; full bars) displayed similar subunit combinations. $D$, Restriction analysis revealed prevailing expression of flip versions. GluR1 flip was more abundant in AHS (asterisk).

determine the receptor subunits expressed by human astrocytes and to identify the subunit(s) that potentially undergoes changes in posttranscriptional splicing. Although the overall expression pattern of GluR subunits was similar in patients with AHS and lesion-associated epilepsy, pharmacological characterization, restriction analysis, and semiquantitative real-time PCR identified a selective increase in the astroglial GluR1 flip/flop ratio in the sclerotic epileptic hippocampus.

\section{Pharmacological analyses of splice variant expression}

Regardless of the form of epilepsy, astrocytes of human hippocampus selectively expressed ionotropic glutamate receptors of the AMPA subtype, but no high-affinity kainate receptors or NMDA receptors, because the responses evoked by kainate or glutamate were always completely blocked by the specific antagonist GYKI53655 (Wilding and Huettner, 1995). This expression profile matches findings in rodent hippocampal astrocytes (GluR cells), which also lack functional kainate and NMDA receptors (Seifert and Steinhäuser, 1995; Matthias et al., 2003). Considering astrocytes from lesion cases as "control-like," we noted that human AMPA receptors displayed a significantly faster desensitization than those of mouse astrocytes (Seifert et al., 1997b), which might reflect species-dependent differences (Mosbacher et al., 1994; Grosskreutz et al., 2003).

Use of the specific AMPA receptor modulators CTZ and
PEPA, which preferentially block desensitization of flip and flop forms of the receptor, respectively (Partin et al., 1994; Sekiguchi et al., 1997), corroborated the previous presumption (Seifert et al., 2002) of differences in flip/flop splicing between hippocampal astrocytes in patients with AHS versus lesion-associated epilepsy. First, experiments with glutamate as the agonist revealed a much slower dissociation of CTZ from the receptor binding site of astrocytes from AHS cases, indicating enhanced expression of flip receptor forms (Fleck et al., 1996). Second, comparison of the potentiation of glutamateevoked currents by PEPA and CTZ and determination of the $\mathrm{P} / \mathrm{C}$ ratio, which allows a rough prediction of the relative expression of flip versus flop splice variants in native cells (Sekiguchi et al., 1998), revealed a lower $\mathrm{P} / \mathrm{C}$ value in astrocytes of AHS specimens, further substantiating the idea of elevated flip versus flop levels in the sclerotic form of TLE.

\section{Molecular analyses of splice variant expression in human astrocytes} Transcript analysis was performed to identify the subunits mediating AMPA receptor currents in human astrocytes and to detect those subunits that were affected in AHS. Single-cell RT-PCR after functional characterization of the human cells revealed preferential expression of mRNAs encoding GluR1, -2, and -4, similar to findings in astrocytes of mouse hippocampus (Seifert et al., 1997a). Astrocytes obtained from AHS patients or lesion-associated specimens displayed the same expression pattern. Subsequent restriction analysis disclosed that the human GluR genes were expressed mainly in the flip splice form. Importantly, quantitative evaluation of the flip/flop ratios revealed enhanced levels of GluR1 flip in astrocytes from AHS cases, whereas the splicing status of the remaining subunits was the same in the two forms of epilepsy. Elevated flip forms in sclerosis versus lesion-associated epilepsy were also confirmed independently with real-time PCR, and direct comparison of the data obtained with the two methods from the same cell mostly found a correlation of flip/flop ratio and $\Delta C_{\mathrm{T}}$ for GluR1. It should be noted that transcript analysis alone, by comparing flip/flop ratios, would not allow us to distinguish between elevated levels of flip or reduced expression of flop. Both the stronger potentiation of kainateinduced responses by CTZ (Seifert et al., 2002) and the slower recovery of glutamate responses from CTZ modulation (this study) also suggested a relative increase in the flip form in AHS. Judging from the similar receptor current densities observed in AHS and lesion-associated epilepsy (Seifert et al., 2002), an upregulation of GluR1 seems unlikely. Rather, our data support a relative increase in GluR1 flip at the expense of GluR1 flop.

Apparently, the GluR 1 subunit is affected not only in astrocytes but also in neurons of the epileptic hippocampus. After kindling, enhanced mRNA levels of the flip forms of GluR1-3 were observed in granule cells of the dentate gyrus (Kamphuis et 
Table 2. Relative frequency of human glial AMPA receptors and differences in alternative splicing

\begin{tabular}{lllll}
\hline & GluR1 & GluR2 & GluR3 & \\
\hline AHS & & & & GluR4 \\
$\quad$ Relative frequency (\%) & $50(8 / 16)$ & $100(16 / 16)$ & $44(7 / 16)$ & $83 \pm 6(6)$ \\
$\quad$ Flip, relative fraction (\%) & $82 \pm 11(7)^{*}$ & $81 \pm 18(14)$ & $7 \pm 6(6)$ & $77 \pm 21(12)$ \\
$\quad$ Flop, relative fraction (\%) & $18 \pm 11(7)^{*}$ & $19 \pm 18(14)$ & & \\
Lesion & & $92(12 / 13)$ & $38(5 / 13)$ & \\
$\quad$ Relative occurrence (\%) & $69(9 / 13)$ & $70 \pm 13(7)$ & $89 \pm 8(3)$ & \\
$\quad$ Flip, relative fraction (\%) & $59 \pm 19(8)^{*}$ & $30 \pm 13(7)$ & $11 \pm 8(3)$ & $82 \pm 10(3)$ \\
$\quad$ Flop, relative fraction (\%) & $41 \pm 19(8)^{*}$ & & $18 \pm 10(3)$ \\
\hline
\end{tabular}

Data give mean $\pm S D$; cell numbers are in parentheses.

*Significant differences between AHS and lesion.

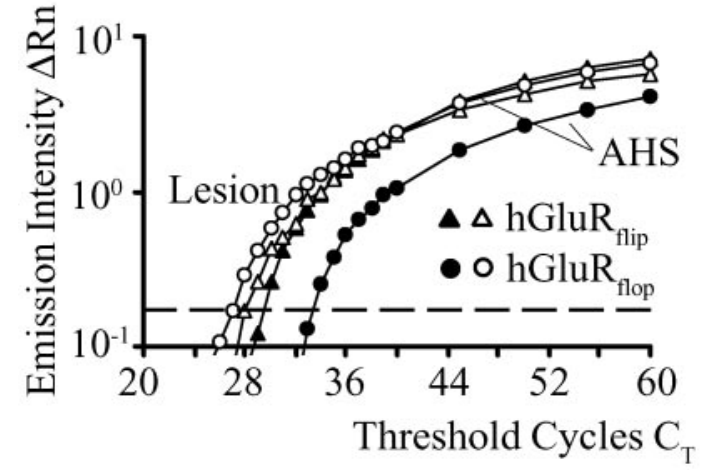

Figure 6. Determination of AMPA-receptor flip/flop ratios in human astrocytes using semiquantitative real-time PCR. Amplification plots of two individual astrocytes from AHS (filled symbols) and lesion specimens (open symbols) are shown. Note the higher cycle number necessary to amplify flop transcripts (circles) in the AHS cell (left). The threshold for detection was set at $\Delta R_{\mathrm{n}}=0.17$ (indicated by the dashed line).

al., 1992), but only GluR1 flip remained elevated in the longlasting kindled state (Kamphuis et al., 1994). In the kainate model of epilepsy, seizure activity led to enhanced GluR2 flip transcripts in the CA1 region (Pollard et al., 1993). In human TLE, hilar mossy cells and CA3 neurons of the sclerotic hippocampus displayed increased GluR1 immunoreactivity, suggesting that this subunit might contribute to the genesis and maintenance of epileptic activity (De Lanerolle et al., 1998; Eid et al., 2002).

Our investigations do not allow us to decide whether the changes in glial receptor splicing are causative for epilepsy or rather a result of the hyperactivity, and the underlying mechanisms that initiate the molecular changes remain to be elucidated. In this context it is interesting to note that growth factors (basic FGF, PDGF) affected expression of GluR1 in cultured glial cells (Chew et al., 1997), because seizure activity has been demonstrated to induce growth factor expression in neurons and glial cells (Gall, 1993; Gall et al., 1994), which in human epileptic hippocampus correlated with neuronal damage and mossy fiber sprouting (Mathern et al., 1997).

\section{Functional implications}

In mouse hippocampus, two types of astrocytes have been identified on the basis of their different morphological, functional, and molecular properties. Specifically, one cell type expressed a complex pattern of time- and voltage-dependent whole-cell currents and glutamate receptors of the AMPA subtype (GluR-cells); the other cell type predominated resting currents and glutamate transporters (GluT-cells) (Matthias et al., 2003). Cells with similar properties are also present in human hippocampus. Strikingly, although GluR-like cells with complex current pattern and functional AMPA receptors reside in both the sclerotic and nonsclerotic forms of TLE, a previous study noted an almost complete loss of astrocytes with time- and voltage-independent currents (GluT-like cells) in hippocampal specimens of patients with AHS (Hinterkeuser et al., 2000). Although the present study focused on GluR-like cells, experiments are currently under way to test whether, in human hippocampus, expression of glutamate transporters is also confined to GluT-like cells. Preliminary data support this presumption because here we report a complete block of glutamate responses by GYKI53655, indicating that human GluR-like cells lack transporter currents. Hence, the loss of GluT-like cells in the CA1 region of AHS patients might contribute to the enhanced extracellular glutamate levels observed in epileptic tissue (Glass and Dragunow, 1995). Excess glutamate in concert with a reduced extracellular space during seizure activity (Lux et al., 1986) may facilitate astrocyte AMPA receptor activation. In rodent hippocampus, NG2-positive glial cells in the CA1 stratum radiatum receive direct synaptic input from glutamatergic CA3 neurons (Bergles et al., 2000), and recent data suggest that these cells include GluR-type astrocytes (Matthias et al., 2003). Hence, after synaptic glutamate release, the enhanced expression of flip forms would prolong receptor activation in astrocytes of the sclerotic human hippocampus, leading to increased depolarization caused by both a cationic influx and a concomitant block of Kir channels. In addition, a persistent reduction of astroglial Kir current density has been reported in the sclerotic human hippocampus (Bordey and Sontheimer, 1998; Hinterkeuser et al., 2000), which can be expected to add to the glial depolarization and further impair the efficiency of the cells to buffer extracellular $\mathrm{K}^{+}$and glutamate. These findings imply that in AHS, altered astrocyte functioning may contribute to the generation or spread of seizure activity.

\section{References}

Bergles DE, Roberts JD, Somogyi P, Jahr CE (2000) Glutamatergic synapses on oligodendrocyte precursor cells in the hippocampus. Nature 405:187-191.

Bordey A, Sontheimer H (1998) Properties of human glial cells associated with epileptic seizure foci. Epilepsy Res 32:286-303.

Chew LJ, Fleck MW, Wright P, Scherer SE, Mayer ML, Gallo V (1997) Growth factor-induced transcription of GluR1 increases functional AMPA receptor density in glial progenitor cells. J Neurosci 17:227-240.

De Lanerolle NC, Eid T, Von Campe G, Kovacs I, Spencer DD, Brines M (1998) Glutamate receptor subunits GluR1 and GluR2/3 distribution shows reorganization in the human epileptogenic hippocampus. Eur J Neurosci 10:1687-1703.

Eid T, Kovacs I, Spencer DD, De Lanerolle NC (2002) Novel expression of AMPA-receptor subunit GluR1 on mossy cells and CA3 pyramidal neurons in the human epileptogenic hippocampus. Eur J Neurosci 15:517-527.

Engel Jr J (1993) Update on surgical treatment of the epilepsies. Neurology 43:1612-1617.

Fleck MW, Bähring R, Patneau DK, Mayer ML (1996) AMPA receptor het- 
erogeneity in rat hippocampal neurons revealed by differential sensitivity to cyclothiazide. J Neurophysiol 75:2322-2333.

Friedman LK, Pellegrini-Giampietro DE, Sperber EF, Bennett MVL, Moshé SL, Zukin RS (1994) Kainate-induced status epilepticus alters glutamate and $\mathrm{GABA}_{\mathrm{A}}$ receptor gene expression in adult rat hippocampus: an in situ hybridization study. J Neurosci 14:2697-2707.

Gall CM (1993) Seizure-induced changes in neurotrophin expression: implications for epilepsy. Exp Neurol 124:150-166.

Gall CM, Berschauer R, Isackson PJ (1994) Seizures increase basic fibroblast growth factor mRNA in adult rat forebrain neurons and glia. Mol Brain Res 21:190-205.

Glass M, Dragunow M (1995) Neurochemical and morphological changes associated with human epilepsy. Brain Res Rev 21:29-41.

Grooms SY, Opitz T, Bennett MVL, Zukin RS (2000) Status epilepticus decreases glutamate receptor $2 \mathrm{mRNA}$ and protein expression in hippocampal pyramidal cells before neuronal death. Proc Natl Acad Sci USA 97:3631-3636.

Grosskreutz J, Zoerner A, Schlesinger F, Krampfl K, Dengler R, Bufler J (2003) Kinetic properties of human AMPA-type glutamate receptors expressed in HEK293 cells. Eur J Neurosci 17:1173-1178.

Hinterkeuser S, Schröder W, Hager G, Seifert G, Blümcke I, Elger CE, Schramm J, Steinhäuser C (2000) Astrocytes in the hippocampus of patients with temporal lobe epilepsy display changes in potassium conductances. Eur J Neurosci 12:2087-2096.

Holland PM, Abramson RD, Watson R, Gelfand DH (1991) Detection of specific polymerase chain reaction product by using the $5^{\prime}-3^{\prime}$ exonuclease activity of Thermus aquaticus DNA polymerase. Proc Natl Acad Sci USA 88:7276-7280.

Hufnagel A, Zentner J, Fernandez G, Wolf HK, Schramm J, Elger CE (1997) Multiple subpial transection for control of epileptic seizures: effectiveness and safety. Epilepsia 38:678-688.

Jabs R, Kirchhoff F, Kettenmann H, Steinhäuser C (1994) Kainate activates $\mathrm{Ca}^{2+}$-permeable glutamate receptors and blocks voltage-gated $\mathrm{K}^{+}$currents in glial cells of mouse hippocampal slices. Pflügers Arch 426:310-319.

Kamphuis W, Monyer H, De Rijk TC, Lopes da Silva FH (1992) Hippocampal kindling increases the expression of glutamate receptor-A Flip and -B Flip mRNA in dentate granule cells. Neurosci Lett 148:51-54.

Kamphuis W, De Rijk TC, Talamini LM, Lopes da Silva FH (1994) Rat hippocampal kindling induces changes in the glutamate receptor mRNA expression patterns in dentate granule neurons. Eur J Neurosci 6:1119-1127.

Kral T, Clusmann H, Urbach J, Schramm J, Elger CE, Kurthen M, Grunwald $\mathrm{T}$ (2002) Preoperative evaluation for epilepsy surgery (Bonn Algorithm). Zentralbl Neurochir 63:106-110.

Lux H-D, Heinemann U, Dietzel I (1986) Ionic changes and alterations in the size of the extracellular space during epileptic activity. Adv Neurol 44:619-639.

Mathern GW, Babb TL, Micevych PE, Blanco CE, Pretorius JK (1997) Granule cell mRNA levels for BDNF, NGF, and NT-3 correlate with neuron losses or supragranular mossy fiber sprouting in the chronically damaged and epileptic human hippocampus. Mol Chem Neuropathol 30:53-76.

Matthias K, Kirchhoff F, Seifert G, Hüttmann K, Matyash M, Kettenmann H, Steinhäuser C (2003) Segregated expression of AMPA-type glutamate receptors and glutamate transporters defines distinct astrocyte populations in the mouse hippocampus. J Neurosci 23:1750-1758.

Medhurst AD, Harrison DC, Read SJ, Campbell CA, Robbins MJ, Pangalos MN (2000) The use of TaqMan RT-PCR assays for semiquantitative analysis of gene expression in CNS tissues and disease models. J Neurosci Methods 98:9-20.
Mosbacher J, Schoepfer R, Monyer H, Burnashev N, Seeburg PH, Ruppersberg JP (1994) A molecular determinant for submillisecond desensitization in glutamate receptors. Science 266:1059-1062.

Partin KM, Patneau DK, Mayer ML (1994) Cyclothiazide differentially modulates desensitization of a-amino-3-hydroxy-5-methyl-4-isoxazolepropionic acid receptor splice variants. Mol Pharmacol 46:129-136.

Pollard H, Héron A, Moreau J, Ben-Ari Y, Khrestchatisky M (1993) Alterations of the GluR-B AMPA receptor subunit flip/flop expression in kainate-induced epilepsy and ischemia. Neuroscience 57:545-554.

Porter JT, McCarthy KD (1996) Hippocampal astrocytes in situ respond to glutamate released from synaptic terminals. J Neurosci 16:5073-5081.

Rogawski MA, Donevan SD (1999) AMPA receptors in epilepsy and as targets for anti-epileptic drugs. Adv Neurol 79:947-963.

Rosa MLNM, Jefferys JGR, Sanders MW, Pearson RCA (1999) Expression of mRNAs encoding flip isoforms of GluR1 and GluR2 glutamate receptors is increased in rat hippocampus in epilepsy induced by tetanus toxin. Epilepsy Res 36:243-251.

Sanchez RM, Koh S, Rio C, Wang C, Lamperti ED, Sharma D, Corfas G, Jensen FE (2001) Decreased glutamate receptor 2 expression and enhanced epileptogenesis in immature rat hippocampus after perinatal hypoxia-induced seizures. J Neurosci 21:8154-8163.

Schröder W, Seifert G, Hüttmann K, Hinterkeuser S, Steinhäuser C (2002) AMPA receptor-mediated modulation of inward rectifier $\mathrm{K}^{+}$channels in astrocytes of mouse hippocampus. Mol Cell Neurosci 19:447-458.

Seifert G, Steinhäuser C (1995) Glial cells in the mouse hippocampus express AMPA receptors with an intermediate $\mathrm{Ca}^{2+}$ permeability. Eur J Neurosci 7:1872-1881.

Seifert G, Steinhäuser C (2001) Ionotropic glutamate receptors in astrocytes. Prog Brain Res 132:287-299.

Seifert G, Rehn L, Weber M, Steinhäuser C (1997a) AMPA receptor subunits expressed by single astrocytes in the juvenile mouse hippocampus. Mol Brain Res 47:286-294

Seifert G, Zhou M, Steinhäuser C (1997b) Analysis of AMPA receptor properties during postnatal development of mouse hippocampal astrocytes. J Neurophysiol 78:2916-2923.

Seifert G, Schröder W, Hinterkeuser S, Schumacher T, Schramm J, Steinhäuser C (2002) Changes in flip/flop splicing of astroglial AMPA receptors in human temporal lobe epilepsy. Epilepsia 43:S162-S167.

Seifert G, Weber M, Schramm J, Steinhäuser C (2003) Changes in splice variant expression and subunit assembly of AMPA receptors during maturation of hippocampal astrocytes. Mol Cell Neurosci 22:248-258.

Sekiguchi M, Fleck MW, Mayer ML, Takeo J, Chiba Y, Yamashita S, Wada K (1997) A novel allosteric potentiator of AMPA receptors: 4-[2(phenylsulfonylamino)ethylthio]-2,6-difluoro-phenoxyacetamide. J Neurosci 17:5760-5771.

Sekiguchi M, Takeo J, Harada T, Morimoto T, Kudo Y, Yamashita S, Kohsaka S, Wada K (1998) Pharmacological detection of AMPA receptor heterogeneity by use of two allosteric potentiators in rat hippocampal cultures. Br J Pharmacol 123:1294-1303.

Verkhratsky A, Steinhäuser C (2000) Ion channels in glial cells. Brain Res Rev 32:380-412.

Wilding TJ, Huettner JE (1995) Differential antagonism of $\alpha$-amino3-hydroxy-5-methyl-4-isoxazolepropionic acid-preferring and kainate-preferring receptors by 2,3-benzodiazepines. Mol Pharmacol 47: 582-587. 